\title{
New Diphenazines with Neuronal Cell Protecting Activity, Phenazostatins A and B, Produced by Streptomyces sp.
}

\author{
Won-Gon Kim, In-Ja Ryoo, Bong-Sik Yun, Kazuo Shin-Ya ${ }^{\dagger}$, \\ Haruo Seto ${ }^{\dagger}$ and ICK-Dong Yoo* \\ Korea Research Institute of Bioscience and Biotechnology, KIST, \\ Yusong, Taejon 305-600, Korea \\ ${ }^{\dagger}$ Institute of Molecular and Cellular Biosciences, The University of Tokyo, \\ Bunkyo-ku, Tokyo 113, Japan
}

(Received for publication April 30, 1997)

\begin{abstract}
Phenazostatins A and B, new diphenazine compounds, were isolated from the culture broth of Streptomyces sp. 833 as new neuronal cell protecting substances which also showed free radical scavenging activity. In the cell assay, phenazostatins $\mathrm{A}$ and $\mathrm{B}$ inhibited glutamate toxicity in N18-RE-105 cells with $\mathrm{EC}_{50}$ values of 0.34 and $0.33 \mu \mathrm{M}$, respectively.
\end{abstract}

It has been reported that L-glutamate, a major neurotransmitter in the central nervous system, is extensively released during brain ischemia and induces subsequent neuronal cell death. ${ }^{1,2)}$ Recent studies indicate that oxygen radicals are produced through a variety of intracellular cascades in such events. ${ }^{2)}$ It was also reported that blockage of glutamate toxicity by free radical scavengers was effective to ameliorate brain ischemia injury. ${ }^{3,4)}$ Recently, some glutamate toxicity inhibitors of microbial origin such as carquinostatin $\mathrm{A}^{5 \text { ) }}$, lavanduquinocin ${ }^{6)}$, and aestivophoenins $\mathrm{A}$ and $\mathrm{B}^{7)}$ have been reported. In the course of our screening for free radical scavengers or inhibitors of glutamate toxicity using the neuronal hybridoma N18-RE-105 cells to prevent the brain ischemia injury, we previously isolated benzastatins $A \sim G^{8 \sim 10)}$. Further investigation have been in isolation of unique diphenazine compounds, phenazostatins A (1) and B (2) (Fig. 1). In addition, two simple phenazines, methyl ester of 6-acetylphenazine-1- carboxylic acid (3) and methyl saphenate ${ }^{11)}$ (4), were also detected in the same culture broth.

We described structure determination of $\mathbf{1}$ and $\mathbf{2}$ in separate paper ${ }^{12}$. We report here the taxonomy of the producing strain, fermentation, isolation, physicochemical properties and biological activities of $\mathbf{1} \sim \mathbf{4}$.

\section{Materials and Methods}

\section{Taxonomy}

Strain 833 was isolated from a soil sample collected in Jechun-city, Chungcheongbook-do, Korea. The taxonomic studies were carried out as described by the International Streptomyces Project (ISP). ${ }^{13)}$ For the evaluation of cultural characteristics, the strain was incubated in ISP media (Difco, U.S.A.) for 14 21 days at $28^{\circ} \mathrm{C}$. The substrate and aerial mass color were assigned by Guide to Color Standard (Nihon, Shikisai Co., Ltd.). Physiological properties including utilization

Fig. 1. Structures of phenazostatins A (1), B (2) and related co-metabolites.<smiles>COC(=O)c1cccc2nc3c(C(C)Oc4ccc5nc6ccccc6nc5c4)cccc3nc12</smiles><smiles>COC(=O)c1cccc2nc3c(C(C)C)cccc3nc12</smiles>

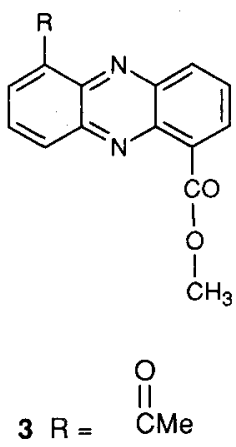

$4 \mathrm{R}=\mathrm{CH}(\mathrm{OH}) \mathrm{Me}$ 
of carbon sources were examined by the method of PridhaM and Gottlieb. ${ }^{14)}$ The type of diaminopimelic acid (DAP) isomers in the cell wall was analyzed by the methods of BECKER et al. ${ }^{15)}$

\section{Media and Fermentation}

A loopful of strain 833 from a mature slant culture was inoculated into a $500 \mathrm{ml}$ Erlenmeyer flask containing $80 \mathrm{ml}$ of sterile seed medium consisting of soluble starch $1 \%$, glucose $2 \%$, soybean meal $2.5 \%$, beef extract $0.1 \%$, yeast extract $0.4 \%, \mathrm{NaCl} 0.2 \%, \mathrm{~K}_{2} \mathrm{HPO}_{4} 0.025 \%$, and $\mathrm{CaCO}_{3} 0.2 \%$ (adjusted to $\mathrm{pH} 7.2$ before sterilization) and cultured on a rotary shaker $(150 \mathrm{rpm})$ at $28^{\circ} \mathrm{C}$ for 2 days. For the production of phenazostatins, $3 \mathrm{ml}$ of the seed culture was transferred into one-liter Erlenmeyer flasks containing $150 \mathrm{ml}$ of the above medium, and cultivated for 6 days using the same conditions. For the study on the time course of production of phenazostatins, each time $10 \mathrm{ml}$ samples of the fermentation broth were drawn. After centrifugation at $3000 \mathrm{rpm}$ for 10 minutes, the $\mathrm{pH}$ value, the packed cell volume (PCV), and the production of phenazostatins were measured. The antibiotics in the broth supernatants were extracted with EtOAc and their concentrations were measured by reserved phase HPLC (Cosmosil $4.6 \times 150 \mathrm{~mm}$ ) with a solution of $\mathrm{MeOH}-\mathrm{H}_{2} \mathrm{O}(85: 15)$ at the UV absorption of $365 \mathrm{~nm}$.

Inhibitory Activity against Glutamate Toxicity in N18-RE-105 Cells

N18-RE-105 cells ${ }^{16)}$ (mouse neuroblastoma clone N18TG-2 $\times$ Fisher rat 18-day embryonic neural retina) were maintained at $37^{\circ} \mathrm{C}$ in $25 \mathrm{~cm}^{2}$ tissue culture flasks in $90 \%$ DMEM containing HAT (thymidine $0.14 \mathrm{~mm}$, aminopterin $40 \mu \mathrm{M}$, hypoxanthine $0.1 \mathrm{~mm}$ ) and $10 \%$ fetal calf serum under a humidified atmosphere of $5 \% \mathrm{CO}_{2}$, $95 \%$ air. Cells were plated in 96 well microplates at a density of 20,000 cells per well with $100 \mu 1$ media. After culturing for 24 hours, the medium was removed and replaced with a medium containing $10 \mathrm{~mm}$ L-glutamate and/or drugs. Cytotoxicity was quantified after treatment for 24 hours by the measurement of the cytosolic enzyme, lactate dehydrogenase ( $\mathrm{LDH}$ ), which was released into the culture medium from degenerating cells. LDH activity was measured using commercial kit purchased from Promega. The percentage of cell death was calculated from the following formula: $\%$ cell death $=A /(A+B) 100$, in which $\mathrm{A}$ and $\mathrm{B}$ are $\mathrm{LDH}$ activity in the culture media (supernatant) and in the cell lysates, respectively. $\mathrm{EC}_{50}$ value is the drug concentration necessary to reduce glutamate-induced cell death by $50 \%{ }^{17)}$

Inhibitory Activity against Lipid Peroxidation in Rat Liver Microsomes

According to the method of OHKAWA et al. ${ }^{18)}$, rat liver microsomes were prepared and suspended in $100 \mathrm{~mm}$ Tris- $\mathrm{HCl}$ buffer ( $\mathrm{pH}$ 7.4). Lipid peroxidation was initiated by adding $500 \mu \mathrm{M} \mathrm{FeSO}_{4} \cdot \mathrm{H}_{2} \mathrm{O}$. After 30 minutes at $37^{\circ} \mathrm{C}$, the reaction was stopped by adding $3 \mathrm{M}$ trichloroacetic acid in $2.5 \mathrm{~N} \mathrm{HCl}$. Lipid peroxidation was assessed by measuring thiobarbituric acid reactive products. Percent inhibition was calculated as follows: $(1-(\mathrm{T}-\mathrm{B}) /(\mathrm{C}-\mathrm{B})) \times 100(\%)$, in which $\mathrm{T}, \mathrm{C}$, and $\mathrm{B}$ are absorbance values at $530 \mathrm{~nm}$ of the drug treatment, the control (peroxidation without a drug) and the 0 time control (no peroxidation), respectively.

\section{Results}

Taxonomic Studies of the Producing Strain

The strain 833 was cultured in various ISP media and the characteristics are summarized in Table 1. The substrate mycelia grew abundantly on yeast-extract - malt extract agar, oatmeal agar, and inorganic salts-starch agar, but grew poorly on glycerol-asparagine agar, tyrosine agar, and glucose-asparagine agar. The aerial mycelia grew abundantly on yeast-extract - malt extract agar and inorganic salts-starch agar, but didn't grow on peptone-yeast extraction iron agar. The aerial mass color was white or grayish white. Sclerotium, sporangium, and zoospores were not observed. The spore chains were observed to be retinaculiaperti type and each had more than ten spores per chain. The spores were cylindrical in shape, were $0.6 \sim 0.7 \times 0.8 \sim 0.9 \mu \mathrm{m}$ in size and had a smooth surface (Fig. 2). The isomer of DAP in whole cell hydrolysates of strain 833 was determined to be the LL-form. The physiological characteristics and the utilization of carbohydrates are shown in Table 2 . Melanoid and soluble pigments were not observed. The strain utilized D-glucose, inositol, D-mannitol, raffinose, D-xylose, cellobiose, and D-galactose, but didn't utilize D-fructose, cellulose, L-arabinose, L-rhamnose, and sucrose. Based on the taxonomic properties described above, strain 833 was determined to belong to the genus Streptomyces. ${ }^{19,20)}$ The strain was deposited in Korean Collection for Type Culture, Korea Research Institute of Bioscience and Biotechnology, Korea, under the accession number KCTC-8796P. 
Table 1. Cultural characteristics of strain 833 .

\begin{tabular}{|c|c|c|c|c|c|}
\hline Medium & Growth & Aerial mycelium & Substrate mycelium & Reverse color & Soluble pigment \\
\hline $\begin{array}{l}\text { Yeast extract-malt extract agar } \\
\text { (ISP medium 2) }\end{array}$ & Good & Abundant, grayish white & Pale yellow & Brown & None \\
\hline Oatmeal agar ( ISP medium 3) & Good & Moderate, white & Pale yellow & Light brown & None \\
\hline $\begin{array}{l}\text { Inorganic salts-starch agar } \\
\text { (ISP medium 4) }\end{array}$ & Good & Abundant, white & Pale brown & Brown & None \\
\hline $\begin{array}{l}\text { Glycerol-asparagine agar } \\
\text { (ISP medium 5) }\end{array}$ & Poor & Poor, grayish white & Yellowish brown & Light brown & None \\
\hline $\begin{array}{l}\text { Peptone-yeast extract-iron agar } \\
\text { (ISP medium 6) }\end{array}$ & Moderate & None & Pale yellow & Yellowish brown & None \\
\hline Tyrosine agar (ISP medium 7) & Poor & Poor, grayish white & Pale brown & Brown & None \\
\hline Glucose-asparagine agar & Poor & Poor, grayish white & Pale brown & Brown & None \\
\hline BENNET's agar & Good & Abundant, whitish gray & Brown & Dark brown & None \\
\hline
\end{tabular}

Fig. 2. Scanning electron micrograph of spore chains of strain 833 on ISP-2 agar incubated at $27^{\circ} \mathrm{C}$ for 2 weeks $(\times 20,000)$.

Bar represents $1 \mu \mathrm{m}$.

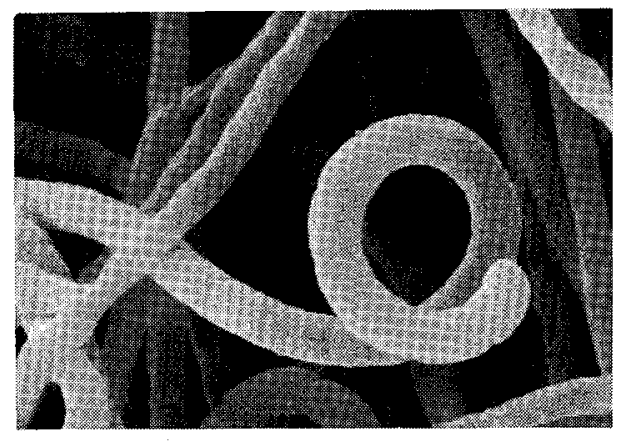

Fermentation

Fig. 3 presents the data for a typical fermentation in one-liter Erlenmeyer flask and give information regarding the production of $\mathbf{1} \sim \mathbf{4}, \mathrm{pH}$, and packed cell volume. The production of $2 \sim 4$ began at day 1 and reached maximun at around day 4 with yield of $2.8,6.7$, and $8.3 \mu \mathrm{g} / \mathrm{ml}$, respectively. Among them, the production of 3 began to decrease drastically after 4 days of cultivation. On the other hand, the production of 1 began at day 4 and reached a maximum $(0.41 \mu \mathrm{g} / \mathrm{ml})$ at day 6 .

\section{Isolation}

The procedure for isolation of phenazostatins A (1), $B(2)$ and related co-metabolites is shown in Scheme 1. The culture supernatant obtained from the culture broth (2 liters) was extracted with an equal volume of hexane three times and the hexane layer was concentrated in
Table 2. Taxonomical characteristics of strain 833 .

\begin{tabular}{lc}
\hline DAP type & LL \\
Spore chain & Retinaculiaperti \\
Spore surface & Smooth \\
Aerial mass color & Grayish white \\
Soluble pigments & None \\
Melanoid pigments & None \\
Growth temperature $\left({ }^{\circ} \mathrm{C}\right)$ & $10-34$ \\
Optimum temperature $\left({ }^{\circ} \mathrm{C}\right)$ & $25-28$ \\
Starch hydrolysis & Positive \\
Nitrate reduction & Positive \\
Gelatin liquefaction & Positive \\
Milk peptonization & Negative \\
Hydrolysis of skim milk & Positive \\
Carbon utilization & \\
D-Glucose & \\
D-Fructose & + \\
Cellulose & - \\
Inositol & - \\
D-Mannitol & + \\
Raffinose & + \\
D-Xylose & + \\
L-Arabinose & + \\
Cellobiose & - \\
D-Galactose & + \\
L-Rhamnose & - \\
Sucrose & + \\
\hline a + Positve untizalon; & + \\
\hline
\end{tabular}

a + , Positive utilization; -, no utilization. vacuo. The crude extract was charged to a silica gel (Merck art No 7734.9025) column followed by elution with hexane-EtOAc $(4: 1)$. Three active fractions containing 3 (fraction I), 1 and 2 (fraction II), and 4 (fraction III) were successively eluted. The fraction II was concentrated in vacuo and applied to a Sephadex 
LH-20 column, which was developed with methanol. The active eluate was further purified by C-18 (YMC-gel ODS-A Lot No. 51252) column chromatography. The column was eluted with $80 \%$ aqueous $\mathrm{MeOH}$ to give two active fractions. These fractions were separately recrystallized in $\mathrm{MeOH}$ to afford $\mathbf{1}(0.8 \mathrm{mg})$ and $\mathbf{2}(8.5 \mathrm{mg})$ as yellow crystals.

Fig. 3. Time course production of phenazostatins A (1), B (2) and related co-metabolites.

$$
\mathrm{pH}(\mathbf{\Lambda}), \operatorname{PCV}(\mathrm{O}), \mathbf{1}(\square), 2
$$

$3(\triangle), 4($
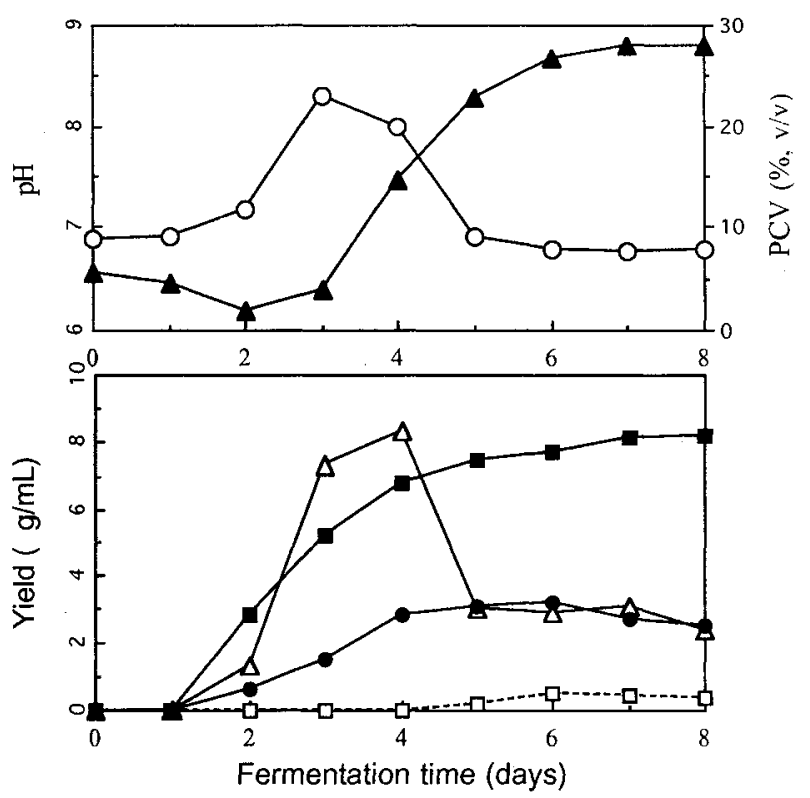

Physico-chemical Properties

Physico-chemical properties of $\mathbf{1}$ and $\mathbf{2}$ are summerized in Table 3. 1 and $\mathbf{2}$ are soluble in chloroform, ethyl acetate, acetone and dimethyl sulfoxide, slightly soluble in methanol and acetonitrile, and insoluble in water and $n$-hexane. After TLC on silica gel $60 \mathrm{~F}_{254}$ (Merck) with $n$-hexane-EtOAC ( $3: 1), 1$ and 2 showed $\mathrm{Rf}$ values of 0.23 and 0.20 , respectively, whereas 3 and 4 had $R f$ values of 0.33 and 0.15 , respectively. The molecular formulas of 1 and 2 were established as $\mathrm{C}_{28} \mathrm{H}_{20} \mathrm{~N}_{4} \mathrm{O}_{3}$ and $\mathrm{C}_{32} \mathrm{H}_{26} \mathrm{~N}_{4} \mathrm{O}_{4}$ by combination of HR-FABMS and ${ }^{13} \mathrm{C}$ NMR spectral data, respectively. The UV absorption maxima near 252 and $365 \mathrm{~nm}$ together with the characteristic low-field chemical shifts of the aromatic protons suggested that these compounds were members of the phenazine class of antibiotics. ${ }^{21)}$ The IR spectra of $\mathbf{1}$ and 2 revealed the characteristic absorption band of an ester group $\left(1730 \sim 1735 \mathrm{~cm}^{-1}\right)$ in their structures. The optical rotation values of $\mathbf{1}$ and $\mathbf{2}$ were zero. It suggests that they exist in nature as mixtures of enantiomers as has been suggested by FLoss et al. ${ }^{22)}$ The ${ }^{1} \mathrm{H}$ NMR spectra of 1 and 2 were shown in Fig. 4.

\section{Biological Activities}

Fig. 5 shows the preventive effects of $1 \sim 4$ on glutamate toxicity in neuronal N18-RE-105 cells. $1 \sim 4$ protected the cells from glutamate toxicity in a dose dependant fashion with $\mathrm{EC}_{50}$ values of $0.34,0.33,0.15$ and $1.28 \mu \mathrm{M}$,

Scheme 1. Isolation procedure of phenazostatins A (1), B (2) and related co-metabolites.

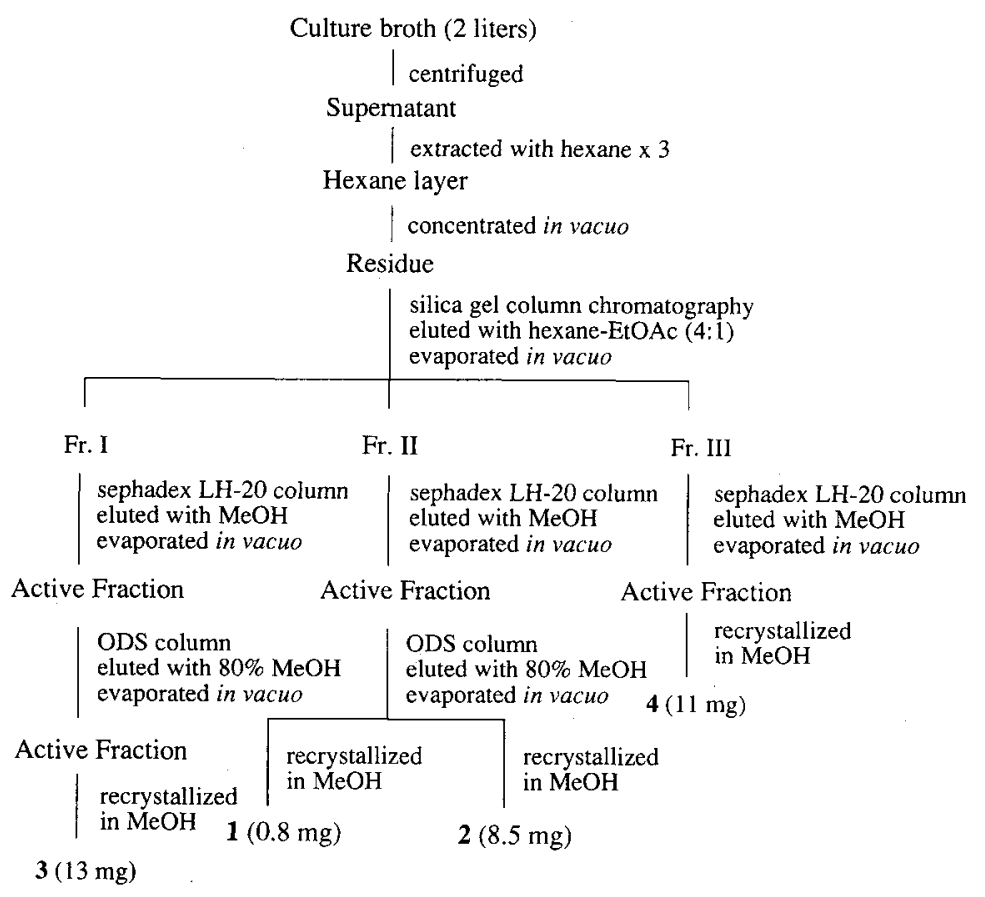


Table 3. Physico-chemical properties of $\mathbf{1}$ and $\mathbf{2}$.

\begin{tabular}{|c|c|c|}
\hline & 1 & 2 \\
\hline Appearance & Yellow crystal & Yellow crystal \\
\hline$[\alpha]_{D}^{18}$ & $0^{\circ}\left(c=0.035, \mathrm{CHCl}_{3}\right)$ & $0^{\circ}\left(c=0.18, \mathrm{CHCl}_{3}\right)$ \\
\hline FAB-MS & $\begin{array}{l}461\left(\mathrm{M}^{+}+1,29.6 \%\right), 279(100), \\
265(78.6), 239(51.6), 197(61.9)\end{array}$ & $\begin{array}{l}531\left(\mathrm{M}^{+}+1,98.4 \%\right), 266(80.0) \\
206(100)\end{array}$ \\
\hline \multicolumn{3}{|l|}{ HRFAB-MS $(m / z)$} \\
\hline found & $461.1626(\mathrm{M}+\mathrm{H})^{+}$ & $531.2040(\mathrm{M}+\mathrm{H})^{+}$ \\
\hline calcd. & 461.1614 & 531.2034 \\
\hline Molecular formula & $\mathrm{C}_{28} \mathrm{H}_{20} \mathrm{~N}_{4} \mathrm{O}_{3}$ & $\mathrm{C}_{32} \mathrm{H}_{26} \mathrm{~N}_{4} \mathrm{O}_{4}$ \\
\hline $\mathrm{UV} \lambda_{\max } \mathrm{nm}(\varepsilon)(\mathrm{MeOH})$ & $252(86,000)$ & $253(89,000)$ \\
\hline & $365(18,000)$ & $366(19,000)$ \\
\hline $\mathrm{IR}(\mathrm{KBr}) \gamma \mathrm{cm}^{-1}$ & $\begin{array}{l}1730,1440,1270,1190 \\
1030,760\end{array}$ & $\begin{array}{l}1735,1530,1280,1265 \\
1240,1190,1040,750\end{array}$ \\
\hline \multicolumn{3}{|l|}{ Solubility } \\
\hline soluble & $\mathrm{CHCl}_{3}, \mathrm{EtOAc}, \mathrm{Me}_{2} \mathrm{CO}, \mathrm{DMSO}$ & $\mathrm{CHCl}_{3}$, EtOAc, $\mathrm{Me}_{2} \mathrm{CO}$, DMSO \\
\hline slightly soluble & $\mathrm{MeOH}, \mathrm{CH}_{3} \mathrm{CN}$ & $\mathrm{MeOH}, \mathrm{CH}_{3} \mathrm{CN}$ \\
\hline insoluble & $\mathrm{H}_{2} \mathrm{O}, n$-Hexane & $\mathrm{H}_{2} \mathrm{O}, n$-Hexane \\
\hline $\operatorname{TLC}(\mathrm{Rf})^{\mathrm{a}}$ & 0.23 & 0.20 \\
\hline $\operatorname{HPLC}\left(\mathbf{R}_{\mathfrak{t}}\right)^{b}$ (minute) & 9.7 & 8.5 \\
\hline
\end{tabular}

a Silica gel TLC (Kieselgel 60F 254 , Merck); solvent, n-Hexane - EtOAc (3:1).

${ }^{b}$ Column, Cosmosil $\mathrm{C}_{18}(4.6 \times 150 \mathrm{~mm})$; solvent, $\mathrm{MeOH}-\mathrm{H}_{2} \mathrm{O}(85: 15)$; flow rate,

$1.2 \mathrm{ml} / \mathrm{min}$; detection, UV absorbance at $365 \mathrm{~nm}$.

Fig. 4. ${ }^{1} \mathrm{H}$ NMR spectra of phenazostatins $\mathrm{A}(\mathbf{1})$ and $\mathrm{B}(2)$ in $\mathrm{CDCl}_{3}(300 \mathrm{MHz})$.

Phenazostatin A

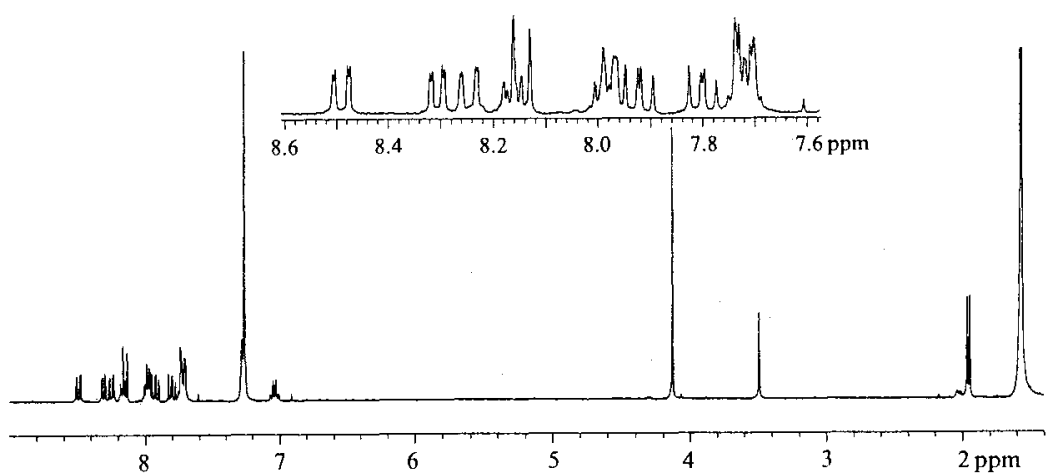

Phenazostatin B

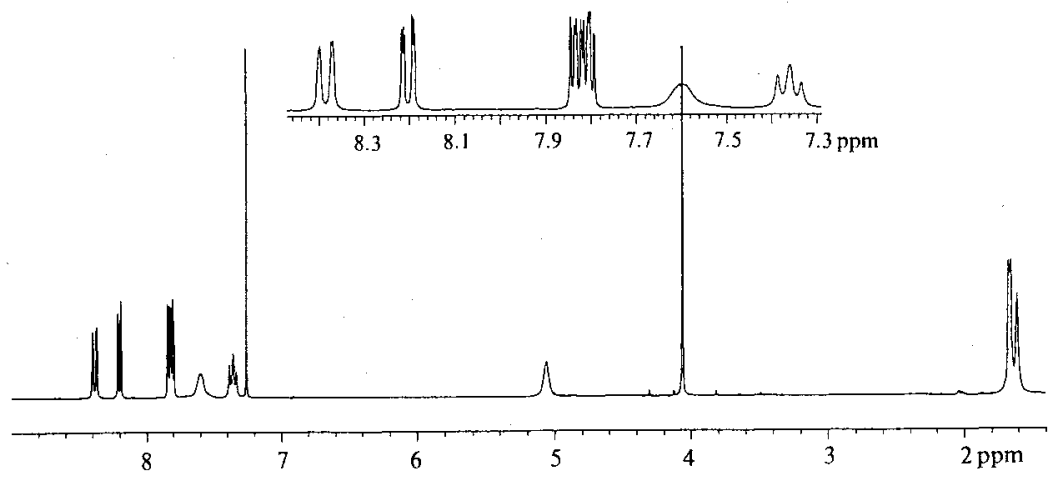


Fig. 5. Effects of $\mathbf{1} \sim \mathbf{4}$ on glutamate toxicity in N18-RE-105 cells and cell viability.

$\mathbf{1}(\square), \mathbf{2}(\bullet), \mathbf{3}(\triangle), \mathbf{4}(\square)$, idebenone $(\bigcirc)$.

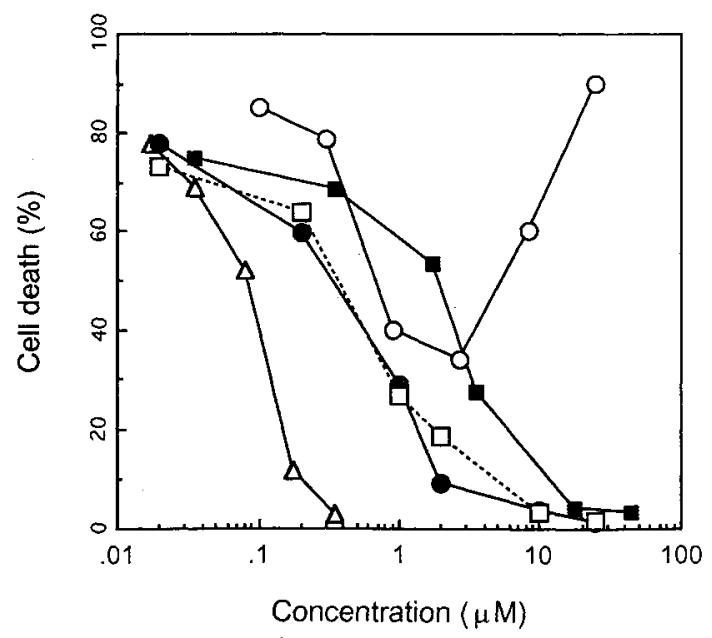

Table 4. Preventive effect against glutamate toxicity $\left(\mathrm{EC}_{50}\right)$, cytotoxicity $\left(\mathrm{IC}_{50}\right)$, and free radical scavenging activity $\left(\mathrm{EC}_{50}\right)$ of $\mathbf{1} \sim \mathbf{4}$.

\begin{tabular}{|c|c|c|c|}
\hline \multirow{2}{*}{ Compounds } & \multicolumn{2}{|c|}{ N18-RE-105 } & \multirow{2}{*}{$\begin{array}{c}\begin{array}{c}\text { Rat liver } \\
\text { microsomes }\end{array} \\
\mathrm{EC}_{50}(\mu \mathrm{M})\end{array}$} \\
\hline & $\mathrm{EC}_{50}(\mu \mathrm{M})$ & $\mathrm{IC}_{50}(\mu \mathrm{M})$ & \\
\hline 1 & 0.34 & $>100$ & 0.51 \\
\hline 2 & 0.33 & $>100$ & 0.44 \\
\hline 3 & 0.15 & $>100$ & 1.42 \\
\hline 4 & 1.28 & $>100$ & 2.60 \\
\hline Vitamin E & 3.73 & $>100$ & 4.21 \\
\hline Idebenone & 0.72 & 4.9 & 4.10 \\
\hline
\end{tabular}

respectively. The inhibition activity of $\mathbf{1}$ and $\mathbf{2}$ was around 2-times higher than that of idebenone ${ }^{23)}$, being used as a brain protective agent. The $\mathrm{EC}_{50}$ and $\mathrm{IC}_{50}$ values of 1 4 in the cell assay are summerized in Table $4.1 \sim 4$ did not show cytotoxicity at $100 \mu \mathrm{m}$ while idebenone exhibited strong cytotoxicity with an $\mathrm{IC}_{50}$ value of $4.9 \mu \mathrm{M}$ in this assay system.

For the purpose of evaluating the antioxidative activity of $\mathbf{1} \sim \mathbf{4}$, the inhibitory activity of these compounds against lipid peroxidation in rat liver microsome was investigated. As shown in Fig. 6, 1 4 also inhibited lipid peroxidation induced by free radicals in rat liver microsomes. The inhibition was dose-dependant. 1 and 2 each showed about the same activity with $\mathrm{IC}_{50}$ values of 0.51 and $0.44 \mu \mathrm{M}$, respectively; which showed about 10-times higher than that of vitamin E. 1 and 2 showed stronger activity than $3(1.42)$ and $\mathbf{4}(2.60 \mu \mathrm{M})$ with simpler phenazine ring system.
Fig. 6. Inhibitory activity of $\mathbf{1} \sim \mathbf{4}$ against lipid peroxidation in rat liver microsomes.

$\mathbf{1}(\square), \mathbf{2}(\bullet), \mathbf{3}(\triangle), \mathbf{4}(\square)$, vitamin $\mathrm{E}(\mathrm{O})$.

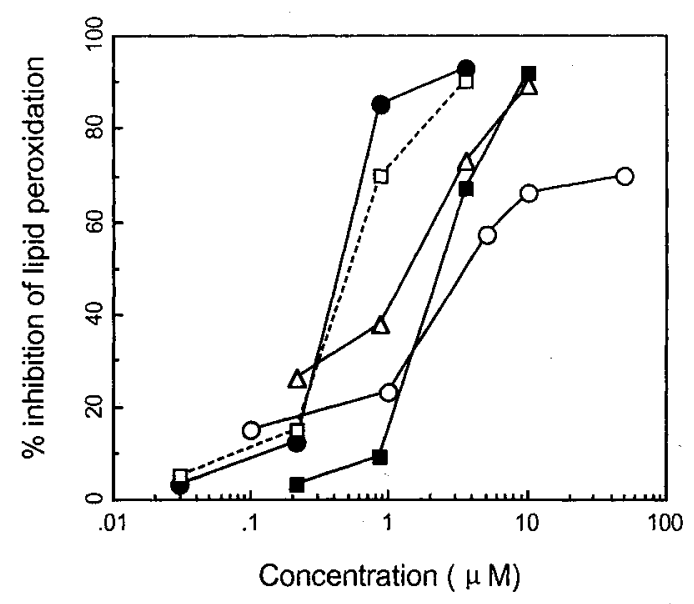

Discussion

In the course of screening for glutamate toxicity inhibitors, we discovered the novel metabolites, phenazostatins A and B, which were isolated from the culture broth of Streptomyces sp. 833. Phenazostatins A and B contain an unique diphenazine skeleton which is only found in the antibiotic esmeraldins $\mathrm{A}$ and $\mathrm{B} .{ }^{26)}$ Phenazostatin B was previously reported by UMEZAwA et $a l^{27)}$ as an inhibitor of phosphodiesterase, but its structural elucidation was undescribed. FLoss et al. ${ }^{22)}$ had demonstrated that the esmeraldins, the diphenazine compounds, were biosynthesized from shikimic acid through the intermediate precursor, 6-aceto-phenazine1-carboxylic acid (i.e. a demethylated compound of 3 ). Thus, 3 could be the biosynthetic precursor of phenazostatins A (1) and B (2). Some phenazine compounds of microbial origin such as aestivophoenins ${ }^{7}$, benthocyanins $^{28)}$, phenazoviridin ${ }^{29)}$, and benthophoenin ${ }^{30)}$ have been reported as free radical scavengers. It has been known that the glutamate toxicity in N18-RE-105 cells is mainly caused by inhibition of cystine uptake, followed by glutathione depletion and consequently oxidative stress. ${ }^{24,25)}$ Since phenazostatins $\mathrm{A}$ and $\mathrm{B}$ exhibited correlated activities against lipid peroxidation and glutamate toxicity, it is very likely that the inhibition of glutamate toxicity is mediated through their antioxidative activity.

\section{Acknowledgments}

This work was supported by the Ministry of Science and Technology, Korea. 


\section{References}

1) CHOI, D. W.: Cerebral hypoxia: some approaches and unanswered questions. J. Neurosci. 10: 2493 2501, 1990

2) Coyle, J. T. \& P: Puttrarcken: Oxidative stress, glutamate, and neurodenegerative disorders. Science 262: $689 \sim 695,1993$

3) Jacoben, E. J.; F. J. Vandoornik, D. A. Ayer, K. L. Belonga, J. M. Braughler, E. D. Hall \& D. J. Houser: 2-(Aminomethyl)chromans that inhibit iron-dependent lipid peroxidation and protect against central nervous system trauma and ischemia. J. Med. Chem. 35: $4464 \sim 4472,1992$

4) Kinouchi, H.; C. J. Epstein, T. Mizui, E. Carlson, S. F. Chen \& P. H. Chan: Attenuation of focal cerebral ischemic injury in transgenic mice overexpressing $\mathrm{CuZn}$ superoxide dismutase. Proc. Natl. Acad. Sci. U.S.A. 88: $11158 \sim 11162,1991$

5) Shin-Ya, K.; M. Tanaka, K. Furihata, Y. Hayakawa $\&$ H. SETO: Structure of carquinostatin A, a new neuronal cell protecting substance produced by Streptomyces exfoliatus. Tetrahadron Lett. 34: 4943 4944, 1993

6) Shin-ya, K.; S. Shimizu, T. Kunigami, K. Furihata, Y. Hayakawa \& H. Seto: A new neuronal cell protecting substance, lavanduquinocin, produced by Streptomyces viridochromogenes. J. Antibiotics 48: $574 \sim 578,1995$

7) Shin-Ya, K.; S. Shimizu, T. Kunigami, K. Furihata, Y. HaYakawa \& H. Seto: Novel neuronal cell protecting substances, aestivophoenins $\mathrm{A}$ and $\mathrm{B}$, produced by Streptomyces purpeofuscus. J. Antibiotics 48: 1378 1381, 1995

8) KIM, W. G.; J. P. Kiм, C. J. Kim, K. H. LeE \& I. D. Yoo: Benzastatins A, B, C, and D: new free radical scavengers from Streptomyces nitrosporeus 30643. I. Taxonomy, fermentation, isolation, physico-chemical properties and biological activities. J. Antibiotics 49: $20 \sim 25,1996$

9) KIM, W. G.; J. P. KIM \& I. D. Yoo: Benzastatins A, B, $\mathrm{C}$, and D: new free radical scavengers from Streptomyces nitrosporeus 30643. II. Structure determination. J. Antibiotics 49: 26 30, 1996

10) Kim, W. G.; J. P. Kim, H. Koshino, K. Shin-ya, H. Seto \& I. D. Yoo: Benzastatins E, F, and G: New indoline alkaloids with neuronal cell protecting activity from Streptomyces nitrosporeus. Tetrahedron 52: $4309 \sim 4316$, 1997

11) Geiger, A.; K.-S. Walter, M. Brandl \& H. Zähner: Metabolites of microorganism. 247. Phenazines from Streptomyces antibioticus strain Tü 2706. J. Antibiotics 41: $1542 \sim 1551,1988$

12) Yun, B. S.; I. J. Ryoo, W. G. Kim, J. P. Kim, H. Koshino, H. SETo \& I. D. Yoo: Structures of phenazostatins A and $B$, neuronal cell protecting substatnces of microbial origin. Tetrahedron Lett. 37: 8529 8530, 1996

13) Shirling, E. B. \& D. Gottlieb: Methods for characterization of Streptomyces species. Int. J. Syst. Bacteriol. 16: 313 340, 1966

14) Pridham, T. G. \& D. GotTlieb: The utilization of carbon compounds by some Actinomycetales as an aid for species determination. J. Bacteriol. 56: $107 \sim$ 114, 1948

15) Becker, B.; M. P. Lechevalier, R. E. Gordon \& H. A. LECHEVALIER: Rapid differentiation between Nocardia and Streptomyces by paper chromatography of whole-cell hydrolysates. Appl. Microbiol. 12: $421 \sim 423,1964$

16) OhKawa, H.; N. OHIshi \& K. YaGi: Assay for lipid peroxides in animals tissues by thiobarbituric acid reaction. Anal. Biochem. 95: 351 358, 1979

17) Malouf, A. T.; R. L. SchnaAR \& J. T. Coyle: Characterization of a glutamic acid neurotransmitter binding site on neuroblastoma hybrid cells. J. Biol. Chem. 259: $12756 \sim 12762,1984$

18) Miyamoto, M.; T. H. Murphy, R. L. Schnaar \& J. T. COYLE: Antioxidants protect against glutamate-induced cytotoxicity in a neuronal cell line. J. Pharmacol. Exp. Ther. 250: $1132 \sim 1140,1989$

19) Nonomura, H.: Key for classification and identification of 458 species of the Streptomyces included in the International Streptomyces Project. J. Ferment. Technol. 52: $78 \sim 92,1974$

20) Shirling, E. B. \& D. GotTlieb: Cooperative description of type cultures of Streptomyces. II. Species descriptions from first study. Int. J. Syst. Bacteriol. 18: 69 189, 1968

21) Berdy, J.; A. Aszaloc, M. Bostian \& K. L. Mcnitt $(E d$.): CRC Handbook of Antibiotic Compounds. Vol. V, CRC Press, Inc., Florida, 1981

22) Van'T LAND, C. W.; U. MoceK \& H. G. Floss: Biosynthesis of the phenazine antibiotics, the saphenamycins and esmeraldins, in Streptomyces antibioticus. J. Org. Chem. 58: $6576 \sim 6582,1993$

23) Sekimoto, H.; I. Nakada, T. Nakano, N. Fuse, K. Haseda, K. Yasumoto, T. Shinagawa, T. Nagai, T. OHKA, S. UCHIYAMa \& T. TAKeCoshi: Efficacy and safety of CV-2619 (idebenone) in multiple cerebral infarction, cerebrovascular dementia and senile dementia. Ther. Res. 2: $957 \sim 972,1985$

24) Murphy, T. H.; M. Miyamoto, A. Sastre, R. L. Schaar \& J. T. CoYle: Glutamate toxicity in a neuronal cell involves inhibition of cystine transport leading to oxidative stress. Neuron 2: $1547 \sim 1558,1989$

25) Murphy, T. H.; R. L. SchaAR \& J. T. CoYle: Immature cortical neurons are uniquely sensitive to glutamate toxicity by inhibition of cystine transport. FASEB J. 4: $1624 \sim 1633,1990$

26) Keller-Schierlein, W.; A. Geiger, H. ZäHNer \& M. BRANDL: 217. Stoftwechselprodukte von mikroorganismen. Die esmeraldine A und B, tief grüne farbstoffe aus Streptomyces antibioticus, Stamm Tü 2706. Helv. Chim. Acta 71: $2058 \sim 2070,1988$

27) Umezawa, H.; T. Takeuchi, M. Hamada \& T. Ito: Microbial production of phenazine derivatives inhibiting phosphodiesterase. CA. 92: 213541p, 1980. Japan, Pat., $80-3733,1980$

28) Shin-ya, K.; K. Furihata, Y. Hayakawa \& H. Seto: The structure of benthocyanin $A$, a new free radical scavenger of microbial origin. Tetrahedron Lett. 32: $943 \sim 946,1991$

29) Kato, S.; K. Shindo, Y. Yamagishi, M. Matsuoka, H. KaWaI \& J. MochIzUKI: Phenazoviridin, a novel free radical scavenger from Streptomyces sp: Taxonomy, fermentation, isolation, structure elucidation and biological activities. J. Antibiotics 41: 1485 1493, 1993

30) Shin-Ya, K.; Y. Hayakawa \& H. Seto: Structure of benthophoenin, a new. radical scavenger produced by Streptomyces prunicolor. J. Nat. Prod. 56: $1255 \sim 1258$, 1993 